\title{
Innovating Support for Research: The Coalescence of Scholarly Communication?
}

\section{Heather Moulaison Sandy, A.J. Million, and Cynthia Hudson-Vitale}

\begin{abstract}
Information professionals housed in academic libraries are increasingly taking a role in supporting scholarly communication activities. This article investigates the extent to which a formal role has grown in ARL libraries, the skills and competencies necessary for supporting work with data in this capacity, and how those skills and competencies relate to the research lifecycle. We find that scholarly communication has formalized in ARL libraries since 2012. We also find that the requisite skills and competencies for scholarly communication work have coalesced since 2009 in support of a core group that, when the research lifecycle is considered, also support the work of scholars.
\end{abstract}

\section{Introduction}

Supporting scholarly communication on university campuses in an age of emerging technologies has naturally fallen to information professionals based in information agencies, such as academic libraries. Given the complexity of these technologies combined with the increasingly sophisticated needs of users, a new breed of information professional must emerge. ${ }^{1}$ In the case of scholarly communication questions, not only must the information professional curate and supply access to scholarship, but he or she must also work with scholars to organize, provide access to, save, and share their work. A sense has emerged that providing specialized support to scholars during the research process has become the purview of the academic library. ${ }^{2}$ But to what extent, and is this assumption founded?

As the needs of scholars have changed, the work of information professionals has evolved in parallel. Traditional library roles have consequently shifted in academic environments, increasingly to support the research process. ${ }^{3}$ Working to support the field of "scholarly communication today reflects a [need to master an ever-growing] constellation of tools, practices, and competencies." 4 The support scholarly communication information professionals provide to researchers varies according to the priorities of the institutions in which they work, the areas of expertise of the scholars whom they support, and their own skills, educational background, and training. But what is it that scholarly communication as a field can hope to support? The expertise needed to support researchers is vast. Based in part on ARL report-

\footnotetext{
* Heather Moulaison Sandy is Associate Professor and Director of Graduate Studies in the School of Information Science E Learning Technologies at the University of Missouri; email: moulaisonhe@missouri.edu. A.J. Million is a Research Investigator in the School of Information at the University of Michigan; email: millioaj@umich.edu. Cynthia Hudson-Vitale is the Head of Research Informatics and Publishing in the Penn State University Libraries; email:cuv185@psu.edu. @2020 Heather Moulaison Sandy, A.J. Million, and Cynthia Hudson-Vitale, AttributionNonCommercial (http://creativecommons.org/licenses/by-nc/4.0/) CC BY-NC.
} 
ing practices, we consider work that supports scholarly communication as assistance with 1) digital curation, 2) research data management, and 3) open access and publishing. When possible, this research study chooses to focus on professional activities related to data but acknowledges the legitimacy and importance of any number of additional foci and areas of expertise.

Although the competencies and skills to support scholarly communication activities in libraries have been codified in several documents (some of which are analyzed in this article), little is known about the growth of scholarly communication work in information agencies. Further, there is a gap in our knowledge about whether and how that work has the potential to support scholarship.

\section{Research Questions and Rationale}

Based on survey data from 2012, the Council of Prairie and Pacific University Libraries (COPPUL) Scholarly Communications Working Group found the field of scholarly communication was not yet coalescing to form a community of practice in libraries. ${ }^{5}$ By 2017, after 10 years of the Association of College \& Research Libraries (ACRL) Scholarly Communication Roadshow, Cross, Oleen, and Perry found the field had significantly matured. ${ }^{6}$ Yet little is known about those working in scholarly communication, ${ }^{7}$ nor about the way their work addresses the needs of scholars participating in the scholarly communication process through the various stages of the research cycle.

Given these points of departure highlighting certain gaps in the literature, this article addresses the following research questions:

RQ1. To what extent has a subarea of scholarly communication practice (such as digital curation) emerged as a cohesive area of practice, and what does it entail?

$R Q 2$. What aspects of the research lifecycle are covered through the creation of Scholarly Communication Librarian positions engaged in digital curation (given the requisite skills and competencies for the work), and what is still needed?

To address these questions, we begin with an investigation of the literature in these areas.

\section{Literature Review}

Scholarly communication is a field that has needed to adapt to modern technology, research approaches, and communication methods. Information professionals supporting scholarly communication have emerged to assist researchers in navigating this new landscape. As Brantley, Bruns, and Duffin explain, "The activities of scholarly communication-support librarians have grown and changed in recent years due to the increasingly complex nature of modern digital scholarship." ${ }^{8}$ For example, Regazzi identifies big data and big science as two changes that have profoundly affected researchers and the work they do. ${ }^{9}$ Hey, Tansley, and Tolle's well-known text also correctly identifies a marked shift toward computational and data-intensive research in the academic environment. ${ }^{10}$ Furthermore, the 2013 U.S. Office of Science and Technology Policy memorandum, "Expanding Public Access to the Results of Federally Funded Research," formally mandated sharing grant-funded research outputs. ${ }^{11}$ 
All of these changes have created a rapidly evolving environment in which scholarly communication professionals now find themselves working.

Scholarly communication information professionals have needed to learn to navigate the increasingly complex field of scholarly communication and its related technologies to support scholars. Thomas and Urban's survey of data librarians identified a number of areas where continuing education and the acquisition of new skills would be beneficial. ${ }^{12}$ Seemingly as a provocation, Thomas and Urban assert that "Data Curation specializations within MLIS programs are designed to provide employable skills for the crucial, growing need for data support services. However, the skills and topics covered in Master of Library and Information Science (MLIS) programs are not adequate for practice in the field." 13 The survey method they employed was informed by a preliminary study of "competencies for data services and how librarians are trained." 14 Their results seem to indicate that those currently working as data librarians found their M(L)IS coursework useful, but they also see many options for continuing education opportunities. ${ }^{15}$ As a result, we surmise that any librarian possessing all the required skills and competencies for data curation would be a kind of "unicorn" who may not exist.

\section{The Evolving Academic Library}

In response to the changing needs of their users, and in support of the new services they must now provide, academic libraries have changed dramatically - they have moved from a front-of-the-house/back-of-the-house binary model to embrace convergence between the two. ${ }^{16}$ In terms of the intersection of digital libraries and scholarly communication, Borgman clarifies that information professionals are more interested in the services digital libraries can provide. ${ }^{17}$ In this way, scholarly communication librarians might be said to resemble both the technical and public services librarians of the past and to be accomplished at discovering and mastering what are potentially new skills and competencies to bridge these activities.

Through an analysis of job ads, Triumph and Beile note that, by 2011, a number of new professional titles had emerged, including the terms Scholarly Communication (as both Electronic Services and Pubic Services positions) and Electronic Resources (as both Electronic Services and Technical Services positions). Other title terms included Digital, Web Services, and Outreach, all with the potential to address multiple traditional areas of librarianship. ${ }^{18}$ Each of these new positions likely carries new duties and responsibilities, so logically the positions require new skills and competencies.

Library reorganization has been a key way in which academic libraries have positioned themselves for the future of access. In examining the literature, Novak and Day identify five steps libraries typically undertake during the reorganization process: libraries 1) identify drivers for change, 2) carry out analysis and diagnosis, 3) communicate the change plan, 4) implement the change, and 5) carry out continuous assessment afterward. ${ }^{19}$ Assigning new tasks to staff based on the analysis-and-diagnosis step takes place during the implementingthe-change step. It is at this point that staff are trained with any new skills they might need and are placed in new positions based on their existing skills, talents, and proclivities. Staff may, therefore, have been hired under one set of requirements or professional expectations and find themselves taking on new work in other areas. There is, as well, no way to be sure that the person hired had the requested skills and experience in the first place, and, as Triumph and Beile note, position announcements can often be a sort of laundry list of desired skills and experience. ${ }^{20}$ As a result, we surmise that an analysis of recent job ads will not reliably describe 
the breadth and depth of work carried out by today's scholarly communication librarians in this rapidly changing information environment.

\section{Supporting Scholarly Communication: Work with Data}

In terms of their work, scholarly communication librarians are responsible for a number of subactivities. In their content analysis of websites and libraries providing research data management services, Yoon and Schultz investigate four areas - service, information, education, and network - as relevant to the needs of the library's clients in an academic, research environment. ${ }^{21}$ Librarians employed by these libraries may be expected to assist faculty and other users with the scholarly communication process writ large. ${ }^{22}$ Promoting the open access movement among library users is also seen as a scholarly communication problem with the potential to improve research impact. ${ }^{23}$

One primary subarea of scholarly communication is digital curation and, by extension, research data management and data curation. To support scholars throughout the research process, scholarly communication information professionals must also assist with the curation and use of data and digital assets in light of the technological advances mentioned earlier. ${ }^{24}$ Indeed, open access and open research services are inherent in the developing of support for research data management and curation. Fearon and his coauthors find that 85 percent of institutions who archive data do so to support open access. ${ }^{25}$ Furthermore, one of the core library services for research data management involves consultations and education around public access to all research outputs: not just data, but also code, analyses, protocols, workflows, publications, and more.

Information professionals working in this area also attempt to understand their users' information needs and digital information preferences. ${ }^{26}$ Lewis, Sarli, and Suiter found that many institutions are developing services to support researchers in managing their scholarly identities and track research outputs. ${ }^{27}$ To support this service, information professionals developed skills in data analysis, digital humanities, data management, and an understanding of various research metric types. In short, as the field has evolved, scholarly communication information professionals have moved from advocating for open scholarship to actively providing services that relate to the communication and publishing of research, research data, and additional aspects of scientific inquiry that make up the research process.

\section{The Research Process}

The research process can be conceptualized in a number of ways, many of which are supported by scholarly communication services in libraries. ${ }^{28}$ To target the delivery of services, the research process must be modeled so libraries can align their services with the needs of scholars. ${ }^{29}$ In particular, research lifecycle models are especially useful for systems and process engineering purposes where academic libraries can restructure to deliver services in a targeted manner. Speaking about how libraries use lifecycle models, Cox and Tam draw attention to how they include aspects of temporality. ${ }^{30}$ Elaborating further, they note that " $[t]$ he metaphor [of a lifecycle] seems to be particularly appealing in the research area because it fits into thinking about designing systems workflows, be those administrative or IT based." ${ }^{31}$ Models can, however, mask the complexity of research, and ineffective models may lead libraries to serve users ineffectively or create unnecessary bureaucracy. ${ }^{32}$ 


\section{Prior Work Examining Models}

To support and document the research process, numerous models have been created by academic libraries, other research support units, and researchers themselves. Many models are available on library or university websites, with several explicitly connecting the work of university support units to phases of the research process, as is the case at the University of Michigan. ${ }^{33}$ Generally, these models apply to specific institutional needs, and there is a substantial amount of variation among them, although recent work by librarians has sought to evaluate models in a comprehensive fashion. Appendix A provides links to several models with a focus on the research process and research data services. Tenopir and colleagues argue that the research-data lifecycle cannot be disentangled from research lifecycles more broadly, so the two may be indistinguishable. ${ }^{34}$

A set of articles describes similarities among models of the research process. For instance, in two articles, Ma and Wang argue lifecycle models can be understood from two perspectives: 1) that of a focus on the value of library research services delivered by librarians; and 2) that of management processes. ${ }^{35}$ Subsequent work classifies models by whether they describe research at the individual, organizational, or community level ${ }^{36}$ or draw attention to data and sociotechnical systems. ${ }^{37}$ Finally, Cox and Tam build on this work from a critical point of view and find that research models can be classified by their 1) scope and point of view, 2 ) elements and processes, and 3) visualization strategies. ${ }^{38}$ Within their three classification areas are thirteen sub-elements that provide granularity for libraries hoping to map scholarly communication research services to the research process.

\section{Theoretical Lens: Diffusion of Innovations}

Rogers's 2003 Diffusion of Innovations (DOI) theory and organizational innovation literature provides concepts to explore the growth of scholarly communication work in academic libraries, as well as the potential to evaluate whether services are likely to be used by patrons. DOI is one of the most cited theories in social scientific literature, ${ }^{39}$ and it is used to explain how and why innovations spread then take hold. An innovation is defined as "any idea, practice, or project that is perceived as new by an individual or other unit of adoption." 40

In this article, we identify one type of innovation as the diffusion of scholarly communication librarianship throughout ARL libraries. Stemming from the work of rural sociologists Ryan and Gross, Rogers's 1962 work is credited with popularizing DOI by synthesizing 508 studies that explained why individuals and organizations adopt innovations. ${ }^{41}$ Rogers's 2003 work identifies four causal factors explaining innovation-adoption decisions: the innovation, communication, time, and a social system. ${ }^{42}$ We focus on innovations (that is to say, scholarly communication positions and the services that they provide, particularly in terms of data) and social systems (in other words, ARL libraries and their clients) below.

\section{Innovation in Organizations}

Organizations are "bod[ies] of people with a particular purpose," and they tend to be complex. ${ }^{43}$ Originally, DOI emerged as a theory that focused on the decisions of individuals such as a university's researchers. Later developments extended it to describe innovation within organizations, such as academic libraries, through the use of metaphors. For example, one metaphor is that of an organizational decision-making process; another metaphor is that of organizational structure. 
Regarding the metaphor of organizational decision-making, one way that Rogers extended DOI was through the creation of a six-part innovation-adoption model. Elaborating on this model, Rogers argues that organizations act as if they possess agency and try to reduce uncertainty about the costs and benefits of adopting and/or rejecting innovations.$^{44}$ We do not focus on internal decisions to create scholarly communication positions in this paper, but Rogers offers a way to infer things about changes in information agencies that have already taken place, through a process of diffusion. ${ }^{45}$ Demonstrated by the creation of scholarly communication positions, we infer that this change pertains to library restructurings that responded to specific research support needs. The creation of scholarly communication-related positions and the work to fill them is ideally connected to the needs of academic researchers.

\section{Formalizing Scholarly Communication Work with Data}

Speaking about management, Jordan and Lloyd argue that human resource planning in libraries calls for the careful selection and recruitment of staff. ${ }^{46}$ One way this is accomplished is to formalize positions by defining job responsibilities to make work predictable and regular. In the case of scholarly communication work with data, the existence of a disciplinary consensus about the skills individuals ought to possess - and the creation of associated positions-would suggest the presence of formalized roles brought about by restructuring.

In Rogers's depiction (or metaphor) of organizational decision-making, he presents multiple elements, two of which relate to the concepts of workplace formalization and restructuring. These elements include: agenda-setting, matching, redefining, restructuring, clarifying, and routinizing. ${ }^{47}$ Agenda-setting refers to where goals and agendas are set by leaders. Matching describes staff searching for and finding solutions to meet agendas. Redefining and restructuring mean that, after the matching stage ends, agendas are refined and innovations are adopted. Finally, clarifying describes the process of generating buy-in from staff, ${ }^{48}$ and routinizing is when staff no longer perceive an innovation as new. ${ }^{49}$

Another metaphor central to this paper is the concept of organizational structure. Pugh says that organizational structures are "regularities in activities such as task allocation, coordination, and supervision," ${ }^{50}$ and Rogers argues there are six structural traits that determine if organizations change. Rooted in organizational innovation literature, these structural traits are: centralization, formalization, complexity, interconnectedness, organizational slack, and size ${ }^{51}$ Formalization describes the extent to which "an organization emphasizes its members' following rules and procedures, ${ }^{\prime 52}$ and we interpret it as information agencies creating positions that align with professionally uniform practices.

Literature examining innovation in organizations from a structural view supports Rogers's arguments - especially when it comes to the matter of formalization. Formalized job roles are associated with slower rates of innovation. For example, in a study of social welfare organizations, Hague and Aiken $^{53}$ found that a low degree of job codification is associated with a high rate of change. In 1981, Howard looked at four university libraries and found that the rate of innovation is negative for centralized, formal, and stratified organizations. ${ }^{54}$ More recently, Chen and Chang looked at 260 organizations via survey and determined that a high degree of organizational formalization slows decision speeds and organizational innovation. ${ }^{55}$ Formalization is not the only predictor of change in organizations, but it does align with the restructuring phase of Rogers's innovation decision-making process. ${ }^{56}$ 


\section{Methodology}

\section{Assessing the Prevalence of Scholarly Communication Positions in ARL Li- braries}

To address our first research question (RQ1) about the extent to which digital curation has emerged as a cohesive area of practice, we begin by investigating the growth of the number of scholarly communication information professionals employed in large academic libraries in North America. Data for positions coded in the Association of Research Libraries (ARL) Salary Survey was investigated. Although ARL institutions are not representative of all information agencies supporting research, they include some of the largest and most prestigious academic libraries in the United States and Canada. Once per year, 125 ARL libraries submit employee data for all positions. Local survey coordinators choose one job code to apply per staff member, and later this data is cleaned, normalized, and aggregated.

For the current study, data for positions coded as Scholarly Communication Librarian (SCHOLAR) and Digital Curation Librarian (DIGICUR) were examined, as these were the most relevant to the three tasks initially defined as comprising the bulk of the work scholarly communication librarians carry out (that is, digital curation, research data management, and open access and publishing). The SCHOLAR code is defined in the salary survey as a library staff member who is involved in scholarly communication. These individuals work with or promote open publication access, provide advice regarding copyright issues, and more. The DIGICUR code is defined as a library staff member who creates and curates digital collections in the sciences, social sciences, or humanities, or who works with data-management issues across multiple disciplines.

As noted earlier, digital curation is a subarea of scholarly communication. Both of these positions were analyzed given their support for the communication and publishing of scholarship, as well as the potential for their focus on supporting researchers and the management of their data. The year 2012 marked the first time ARL collected data regarding these two categories, and data for analysis was available through 2017.

\section{Skills and Competencies Assessment}

In addressing the first research question, this project also analyzed the recommended skills and competencies required for digital curation and data management, an area of expertise that blends back-of-the-house technology expertise with front-of-the-house service provision in support of the scholarly communication process. The project team applied a multistep approach: 1) the identification of relevant guidelines; 2 ) compilation of competencies/skills as a way to enable uniform markup during coding; 3 ) inductive development of broad categories; and 4) coding of each competency to a category.

To find as many relevant digital curation skills and recommendation reports or research studies possible, the following approach was applied:

1. Databases searched: Library Literature \& Information Science; Library, Information Science \& Technology Abstracts; Google Scholar; Google

2. Keywords used: "digital curation skills"; "digital curation curriculum"; "digital curation training"

This search returned 418 articles. Given that we sought to understand competencies and skills for digital curation and research data management-a specific subset of work carried out by scholarly communication information professionals-documents focusing on practice 
rather than theory were retained. Given the evolving nature of the field that was identified through the literature review, 2007 was identified as the very beginning of the field as currently practiced, with the acknowledgment that the field remained somewhat in flux as late as 2012. Articles analyzing position announcements were deemed unreliable since there was no way to know how successful searches would be or how closely incumbents would meet requirements and would carry out work as described. ${ }^{57}$ With this in mind, we developed and applied the following inclusion criteria to narrow search results:

1. Published 2007 to the present;

2. Written in English;

3. Specifically indicated necessary or recommended competencies/skills for properly curating or stewarding data; and

4. Competencies/skills were not developed by analyzing job advertisements or reviewing the literature.

The following three competency documents were analyzed: Librarians' Competencies Profile for Research Data Management from 2016, Matrix of Digital Curation Knowledge and Competencies from 2009, and Preparing the Workforce for Digital Curation from 2015. ${ }^{58}$ Below, we present each in chronological order based on publication dates.

The Matrix of Digital Curation Knowledge and Competencies, published in 2009, is one of the earliest documents articulating the requisite skills for digital curation work. These skills were developed as part of the DigCCurr project led by Helen Tibbo and Cal Lee at the University of North Carolina as part of an Institute of Museum and Library Services (IMLS) project. This IMLS-funded project developed library school curricula and held a number of training events to support the diffusion of digital curation activities. A project matrix composed of six dimensions was developed as a method to identify and organize material to be covered in digital curation curricula. These dimensions are: (1) mandates, values, and principles; (2) functions and skills; (3) professional, disciplinary, institutional, organizational, or cultural context; (4) type of resource; (5) prerequisite knowledge; and (6) transition point in information continuum. The dimension "function and skills" was the source for this research, because it is defined as "know how," as opposed to conceptual, attitudinal, or declarative knowledge.

In 2015, the National Research Council of the U.S. National Academies of Science released the report Preparing the Work-force for Digital Curation. This report was authored by a committee on "Future Career Opportunities and Educational Requirements for Digital Curation" and was intended to examine workforce-related issues in information agencies with an eye toward economic development. The committee was composed of experts and industry representatives in library and information science, labor economics, and domain-specific scientific fields. More recently, the Librarians' Competencies Profile for Research Data Management was published in 2016 by the Joint Task Force for Librarians' Competencies in Support of E-Research and Scholarly Communication, convened by the ARL. The aim of this task force was to outline the competencies needed for e-research, repository management, and scholarly communication. The task force consisted of representatives from ARL institutions, the Canadian Association of Research Libraries, the Confederation of Open Access Repositories, and the Association of European Research Libraries.

\section{Compilation of Competencies}

The three competency guidelines varied in length and detail; two were documents, and one was a matrix of skills. Formats also varied, with one being an HTML document and two being 
in PDF format. To normalize these documents, a PDF was made of the HTML document. Next, using Adobe Acrobat Pro, we documented codes by highlighting relevant text and inserting comments for each competency. The level of detail for each competency document varied. The Matrix of Digital Curation Knowledge and Competencies included function categories, such as "access" and "administration" and sublevel functions, such as the "generation of dissemination information package," which went into great detail about each overarching category. To ensure comparison across the competency documents was reliable, we also used high-level descriptions and text in the definition and explanation section of each document to conduct the qualitative coding process.

\section{Inductive Coding}

Content analysis is an appropriate methodology for understanding and reducing information from existing data sources such as competency documents. Because no taxonomy of qualitative competency guidelines exists for digital curation, we employed an inductive structural coding approach, which involved identifying concepts and skills that may apply to large segments of text and enabled the comparison of frequency counts across cases. ${ }^{59}$ Inductive coding means that coded skills reflect the content found in source documents rather than the skill categories being predetermined by the researchers or based on existing taxonomies. Each document was read by a team member and a list of skills was developed.

To allow for comparisons, and the next coding step across documents, broad categories or buckets of skills were created. For example, the category of research workflows includes skills such as the ability of a curator to understand research practices, workflows, and/or the ability of the curator to understand disciplinary norms and standards. After categories were developed, the competency documents were then recoded for each category. As competencies or skills were mentioned, the researchers recorded instances for each category. The full data set is available online. ${ }^{60}$

\section{Selection of a Research Model}

To address the second research question (RQ2) regarding stages of the research lifecycle potentially covered through the creation of Scholarly Communication Librarian positions, this project assesses the extent to which the work carried out as part of the digital curation and data management workflow addresses the needs of scholars. Stages of the research lifecycle are identified and mapped to the skills and competencies of scholarly communication librarians working with data. Informed by the classification areas provided by Cox and Tam, a model developed by the Research Information Network (RIN) and the National Endowment for Science, Technology, and the Arts (NESTA) in the United Kingdom was selected for study. This model is published in the report Open to All? Case Studies of Openness in Research, and it evaluated six research groups from multiple disciplines to better understand "how principles of openness are translated into practice." ${ }^{11}$ Figure 1 shows this research lifecycle, and table 2 defines its component parts.

For this study's purposes, the RIN/NESTA model was considered best because it was sufficiently broad to allow for the connection of scholarly communication competencies to the "whole of the research process," 62 which is what this project intends to evaluate. It, therefore, occupies a metaphorical "sweet spot" - using Cox and Tam's classification areas and associated sub-elements. Specifically, not only does the RIN/NESTA model focus on the complete 
research lifecycle, but it also centers on research in scholarly communities, is highly abstract, is unidirectional, and refers to processes and cycles; additionally, it takes an open-science point of view. ${ }^{63}$ Furthermore, the RIN/NESTA model was relevant to this study, because it demonstrates "the sheer variety of types and sources of data used in a single field of research; [other] lifecycles typically do this less well." ${ }^{64}$ Addressing this issue was important, because skills and competencies were to be mapped to research activities without oversimplifying the complexity of the research that scholars conduct and the varied organizational contexts in which they operate.

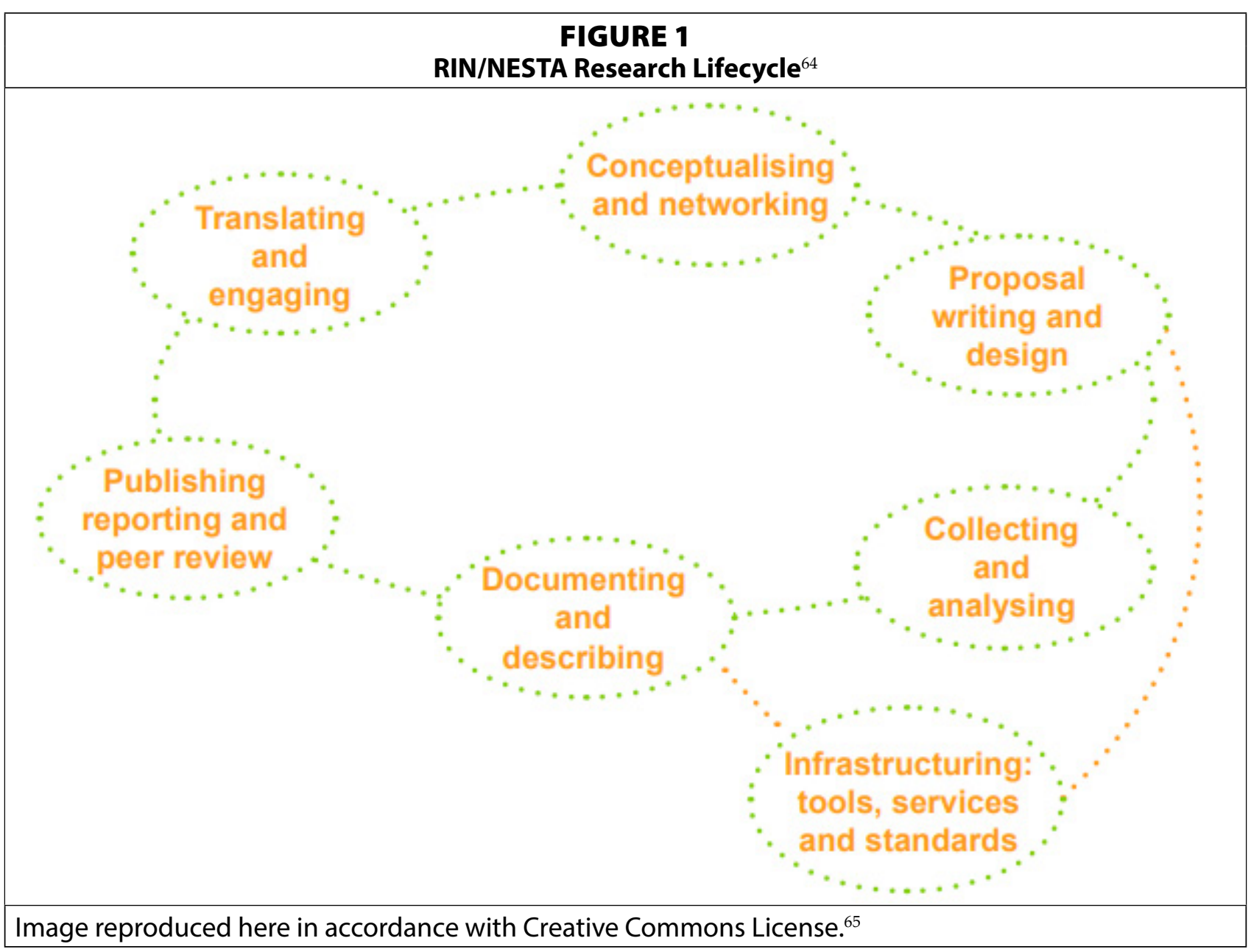

The RIN/NESTA model was not the only model that accounted for variety in types and sources of data in research; it reinforced, however, the point made by Ma and Wang that lifecycle models also describe the research process in terms of value-added support and process management. ${ }^{66}$ The RIN/NESTA model also could be connected to multiple levels of work at the individual, organizational, and community level.$^{67}$ Another model, created by Grigorov et al., was similar in terms of its strengths, which was modeled on work by Tenopir and colleagues, but because the RIN/NESTA model more clearly operationalized terms and definitions (again, see table 2), it more effectively facilitated the mapping process for this study. ${ }^{68}$ 


\section{Findings}

\section{Number of Scholarly Communication Librarians in ARL Libraries}

The number of scholarly communication librarians has been steadily on the rise since 2012 when ARL data was first collected, as is demonstrated in figure 2. Between 2012 and 2017, scholarly communication positions with the job titles scholarly communication (SCHOLAR: focusing on open access and the like) and digital curation (DIGICUR: focusing on research data management and such) increased annually in ARL libraries, though the increase slowed over time. As indicated previously, 2012 marked the first year that ARL collected data for these positions; in 2012, ARL combined its SCHOLAR data with other codes given the low number of positions and is, therefore, the only code presented for 2012. Interestingly, as shown below, growth in digital curation positions totaled 27 percent. Scholarly communication growth was far more rapid, with an increase of 49 percent. A conclusion to draw is that the number of scholarly communication librarians in ARL libraries has grown since data was first collected and that the total of the two combined (as of 2017) was roughly 230 individuals. Additionally, growth numbers matched Rogers's diffusion s-curve.

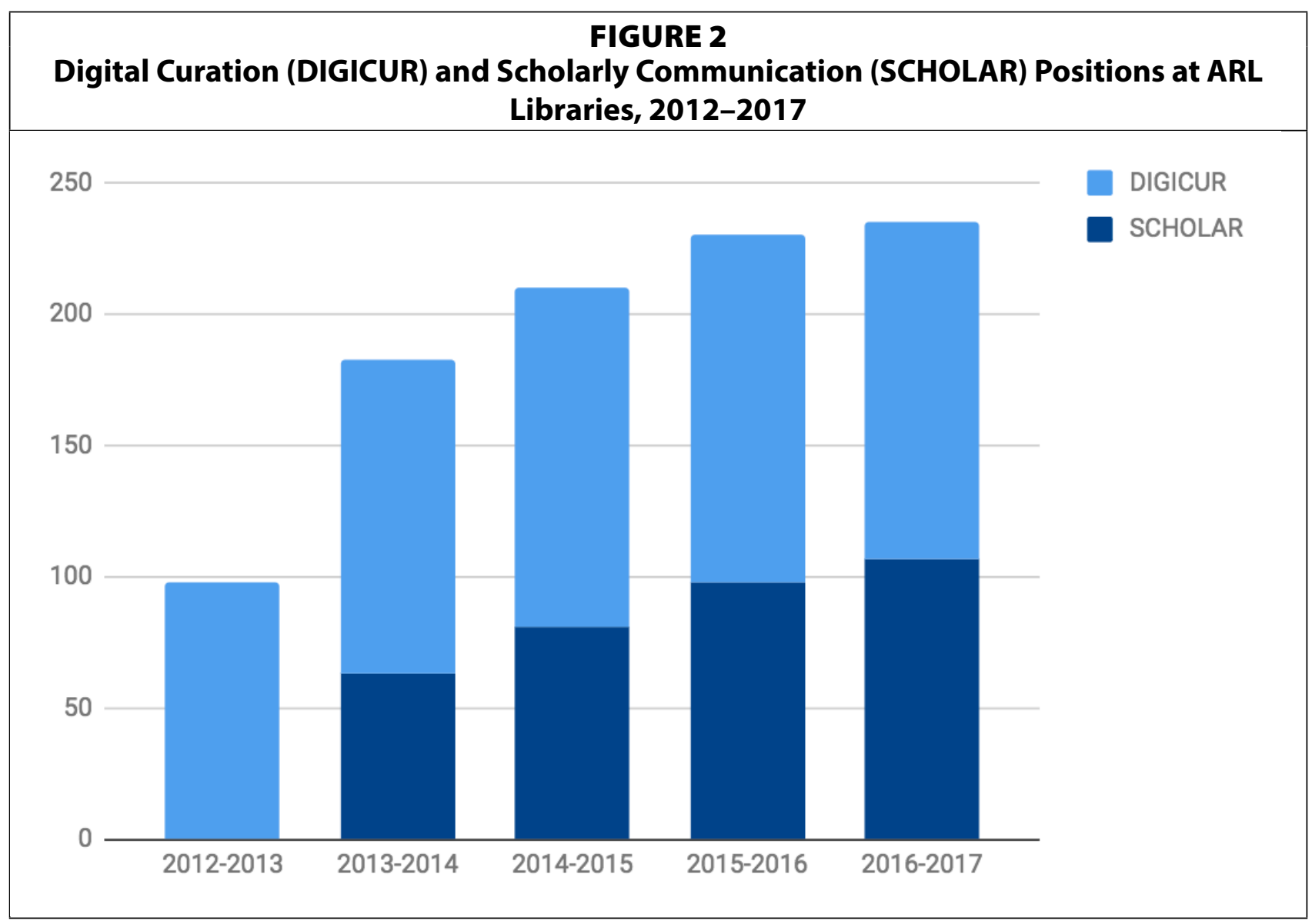

\section{Identification of Competencies and Agreement within Documents over Time}

Coding of the competencies examined in this article identified 23 categories for information professionals to perform digital curation and/or research data management work (see table 1). Of these categories, 12 were found across all three competency publications. These 12 skills are: advocacy and outreach, instruction, data preservation, data management, data selection, 
data repository platforms, data linking, data audits, data type best practices, licensing data, data organization, and information discovery. Because of their prevalence, these 12 skills/ competencies might be considered CORE. An additional seven skills were found across two competency documents. These skills were: some type of discipline knowledge, data analysis skills, an understanding of funder requirements, knowledge of research workflows, data citation, data sharing, and data visualization skills. These might be considered to be newer or emerging, since all but one appears in the two most recent documents. Finally, four skills were limited to only one competency document. These skills were: data security; programming and scripting; a background in science, technology, engineering, or medicine; and an understanding of publisher requirements. These skills/competencies, although helpful, might not be central to the field of scholarly communication and are auxiliary.

\begin{tabular}{|l|l|l|l|l|}
\hline \multicolumn{5}{|c|}{$\begin{array}{l}\text { TABLE 1 } \\
\text { Skills Required for Digital Curation Per the Selected Guidelines Documents and Their } \\
\text { Grouping }\end{array}$} \\
\hline $\begin{array}{l}\text { Competency or Skill } \\
\text { (listed alphabetically by } \\
\text { grouping) }\end{array}$ & $\begin{array}{l}\text { Matrix of } \\
\text { Digital Curation } \\
\text { Knowledge } \\
(\mathbf{2 0 0 9})\end{array}$ & $\begin{array}{l}\text { Preparing the } \\
\text { Workforce for } \\
\text { Digital Curation } \\
\text { (2015) }\end{array}$ & $\begin{array}{l}\text { Librarians' } \\
\text { Competencies Profile } \\
\text { for Research Data } \\
\text { Management (2016) }\end{array}$ & $\begin{array}{l}\text { Status of Skill/ } \\
\text { Competency }\end{array}$ \\
\hline Advocacy and outreach & 1 & 1 & 1 & CORE \\
\hline Data audit & 1 & 1 & 1 & CORE \\
\hline Data linking & 1 & 1 & 1 & CORE \\
\hline Data management & 1 & 1 & 1 & CORE \\
\hline Data organization & 1 & 1 & 1 & CORE \\
\hline Data preservation & 1 & 1 & 1 & CORE \\
\hline Data repository platform & 1 & 1 & 1 & CORE \\
\hline Data selection & 1 & 1 & 1 & CORE \\
\hline Data types best practices & 1 & 1 & 1 & CORE \\
\hline Information discovery & 1 & 1 & 1 & CORE \\
\hline Instruction & 1 & 1 & 1 & CORE \\
\hline Licensing data & 1 & 1 & 1 & CORE \\
\hline Discipline knowledge & 0 & 1 & 1 & EMERGING \\
\hline Data analysis & 0 & 1 & 1 & EMERGING \\
\hline Funder requirements & 0 & 1 & 1 & EMERGING \\
\hline Research workflows & 0 & 1 & 1 & EMERGING \\
\hline Data citation & 0 & 1 & 1 & EMERGING \\
\hline Data sharing & 0 & 1 & 1 & EMERGING \\
\hline Data visualization & 1 & 1 & 0 & EMERGING \\
\hline Data security & 0 & 1 & 0 & AUXILIARY \\
\hline $\begin{array}{l}\text { Programming and } \\
\text { scripting }\end{array}$ & 0 & 0 & 1 & AUXILIARY \\
\hline Education in STEM & 0 & 0 & 1 & \\
\hline Publisher requirements & 0 & 1 & 1 & \\
\hline
\end{tabular}


As noted above, competencies documents possessed a high degree of agreement expressed in skill categories. Out of the 23 skills and competencies identified, all three documents were in agreement about the requirement of 12 of them. Such agreement is notable, because all three documents were written by separate groups during the past decade with notable disciplinary qualifications. An evolution in the field may be evident, however, when comparing the two most recent documents to each other (from 2015 and 2016), as well as to the first document (from 2009). Of the three, the two most similar were the two most recent documents: Librarians' Competencies Profile for Research Data Management (from 2015) and Preparing the Workforce for Digital Curation (from 2016) with more than 78 percent agreement (18 of 23 skills). The Matrix of Digital Curation and the Preparing the Workforce for Digital Curation documents had the next closest agreement, with 61 percent (14 out of 23) points of overlap.

\section{Mapping Scholarly Communication Work to the Research Process}

The RIN/NESTA research lifecycle includes seven distinct stages, many of which are multifaceted and require a variety of knowledge and skills beyond subject expertise. The lifecycle model defines each stage and may be connected to associated research outputs. Each stage of the research cycle and associated outputs must be supported by specialized skills and competencies. Taking the skills and competencies identified in the documents describing scholarly communication work, the research team mapped these skills and competencies directly to the research process; all mappings were discussed by the entire team for 100 percent consensus (see table 2). We find that all aspects of the research process can find support, to some degree or another, when turning to scholarly communication information professionals.

\begin{tabular}{|l|l|l|}
\hline \multicolumn{3}{|c|}{ TABLE 2} \\
\hline \multicolumn{2}{|l|}{ Alignment between RIN/NESTA Lifecycle and Scholarly Communications Competencies } \\
\hline $\begin{array}{l}\text { RIN/NESTA Research lifecycle } \\
\text { stage, from the researcher's } \\
\text { perspective }\end{array}$ & $\begin{array}{l}\text { Research outputs } \\
\text { as identified by } \\
\text { RIN/NESTA }\end{array}$ & $\begin{array}{l}\text { Skills/competencies for scholarly } \\
\text { communication librarians (see Table 1) } \\
\text { (supplied alphabetically) }\end{array}$ \\
\hline $\begin{array}{l}\text { Conceptualising and } \\
\text { networking: sharing new research } \\
\text { concepts and discussing possible } \\
\text { areas for collaboration }\end{array}$ & $\begin{array}{l}\text { Messages, posts, } \\
\text { user profiles, } \\
\text { bibliographies, } \\
\text { résumes }\end{array}$ & $\begin{array}{l}\text { Advocacy and outreach (CORE): engagement } \\
\text { with local community; outreach and } \\
\text { programming } \\
\text { Discipline knowledge (EMERGING): some } \\
\text { knowledge of discipline }\end{array}$ \\
\hline $\begin{array}{l}\text { Proposal writing and design: } \\
\text { sharing and discussing drafts of } \\
\text { proposals and designs, including } \\
\text { communication with funders or } \\
\text { institutional bodies on regulatory } \\
\text { compliance issues }\end{array}$ & $\begin{array}{l}\text { Proposal drafts, } \\
\text { data management } \\
\text { plans, regulatory } \\
\text { compliance } \\
\text { documentation, } \\
\text { study protocols }\end{array}$ & $\begin{array}{l}\text { Data audit (CORE): undertake data audit and } \\
\text { use assessment tools } \\
\text { Data management (CORE): ability to } \\
\text { actively manage research data; provide data } \\
\text { management plan services } \\
\text { Funder requirements (EMERGING): } \\
\text { knowledge of funders' policies and } \\
\text { requirements; knowledge of DMP's } \\
\text { Research workflows (EMERGING): understand } \\
\text { research practices and workflows; understand } \\
\text { disciplinary norms and standards for DM }\end{array}$ \\
\hline
\end{tabular}




\begin{tabular}{|c|c|c|}
\hline \multicolumn{3}{|c|}{$\begin{array}{c}\text { TABLE } 2 \\
\text { Alignment between RIN/NESTA Lifecycle and Scholarly Communications Competencies }{ }^{69}\end{array}$} \\
\hline $\begin{array}{l}\text { RIN/NESTA Research lifecycle } \\
\text { stage, from the researcher's } \\
\text { perspective }\end{array}$ & $\begin{array}{l}\text { Research outputs } \\
\text { as identified by } \\
\text { RIN/NESTA }\end{array}$ & $\begin{array}{l}\text { Skills/competencies for scholarly } \\
\text { communication librarians (see Table 1) } \\
\text { (supplied alphabetically) }\end{array}$ \\
\hline $\begin{array}{l}\text { Collecting and analysing: } \\
\text { performing and documenting the } \\
\text { collection and analysis of data or } \\
\text { other research materials }\end{array}$ & $\begin{array}{l}\text { Raw and derived } \\
\text { data, metadata, } \\
\text { presentations, } \\
\text { podcasts, posters, } \\
\text { workshop papers }\end{array}$ & $\begin{array}{l}\text { Data analysis (EMERGING): knowledge of } \\
\text { data manipulation and analysis techniques } \\
\text { Data citation (EMERGING): knowledge of data } \\
\text { citation and referencing practices (i.e., finding } \\
\text { prior datasets from prior studies) } \\
\text { Data selection (CORE): ability to select and } \\
\text { appraise datasets } \\
\text { Information discovery (CORE): ability to } \\
\text { discover appropriate information sources or } \\
\text { data repositories }\end{array}$ \\
\hline $\begin{array}{l}\text { Infrastructuring: contributing } \\
\text { to development of community } \\
\text { standards, tools and databases or } \\
\text { other shared resources }\end{array}$ & $\begin{array}{l}\text { Lab notes, research } \\
\text { memos, study- } \\
\text { level metadata, } \\
\text { supplementary } \\
\text { information }\end{array}$ & $\begin{array}{l}\text { Data citation (EMERGING): knowledge of data } \\
\text { citation and referencing practices (i.e., data } \\
\text { generated by the researcher) } \\
\text { Data sharing (EMERGING): articulate benefits } \\
\text { of data sharing and re-use }\end{array}$ \\
\hline $\begin{array}{l}\text { Documenting and describing: } \\
\text { completing and reviewing final } \\
\text { documentation or structured } \\
\text { metadata prior to publication } \\
\text { or submission to an archive or } \\
\text { repository }\end{array}$ & $\begin{array}{l}\text { Conference papers, } \\
\text { journal articles, } \\
\text { technical reports }\end{array}$ & $\begin{array}{l}\text { Data security (AUXILIARY): ability to } \\
\text { recommend/implement a data security } \\
\text { program } \\
\text { Data type best practices (CORE): knowledge } \\
\text { of best practices for data structures, types, } \\
\text { formats, vocabularies, metadata; knowledge } \\
\text { of metadata standards } \\
\text { Licensing data (CORE): data licensing and } \\
\text { intellectual property issues; knowledge } \\
\text { of data sharing options, open access, IPR, } \\
\text { licenses }\end{array}$ \\
\hline $\begin{array}{l}\text { Publishing, reporting, and } \\
\text { peer review: preparing and } \\
\text { communicating articles, reports, } \\
\text { or other products of the research. } \\
\text { Taking part in peer reviews of } \\
\text { third-party research outputs, or } \\
\text { informally commenting and rating } \\
\text { these }\end{array}$ & $\begin{array}{l}\text { General articles, } \\
\text { web pages, } \\
\text { briefings, } \\
\text { public exhibits, } \\
\text { presentations }\end{array}$ & $\begin{array}{l}\text { Data linking (CORE): knowledge of data } \\
\text { linking and data integration techniques } \\
\text { Publisher requirements (AUXILIARY): } \\
\text { knowledge of data publication requirements } \\
\text { and journals }\end{array}$ \\
\hline $\begin{array}{l}\text { Translating and engaging: } \\
\text { involving the envisaged users of } \\
\text { the research in actual or potential } \\
\text { applications of it, in other research } \\
\text { fields, commercialisation or policy }\end{array}$ & $\begin{array}{l}\text { Software tools, } \\
\text { databases, } \\
\text { repositories, web } \\
\text { services, schemas } \\
\text { and standards }\end{array}$ & $\begin{array}{l}\text { Data organization (CORE): understanding } \\
\text { of the way data are organized and structured } \\
\text { within collections; database design types } \\
\text { Data preservation (CORE): ability to } \\
\text { undertake digital preservation activities } \\
\text { Data repository platforms (CORE): } \\
\text { knowledge of data repository and storage } \\
\text { platforms; archival storage } \\
\text { Data visualization (EMERGING): information } \\
\text { design and visualization }\end{array}$ \\
\hline
\end{tabular}




\section{TABLE 2}

Alignment between RIN/NESTA Lifecycle and Scholarly Communications Competencies ${ }^{69}$

\begin{tabular}{|l|l|l|}
\hline $\begin{array}{l}\text { RIN/NESTA Research lifecycle } \\
\text { stage, from the researcher's } \\
\text { perspective }\end{array}$ & $\begin{array}{l}\text { Research outputs } \\
\text { as identified by } \\
\text { RIN/NESTA }\end{array}$ & $\begin{array}{l}\text { Skills/competencies for scholarly } \\
\text { communication librarians (see Table 1) } \\
\text { (supplied alphabetically) }\end{array}$ \\
\hline & $\begin{array}{l}\text { Not included: } \\
\text { Education in STEM (AUXILIARY): background } \\
\text { in STEM } \\
\text { Instruction (CORE): ability to teach a variety } \\
\text { of data and digital literacy topics } \\
\text { Programming and scripting (AUXILIARY): } \\
\text { ability to program or script in Python, Perl, etc. }\end{array}$ \\
\hline
\end{tabular}

\section{Discussion}

\section{Cohesiveness of Scholarly Communication Activities}

To address the question of the trajectory of positions supporting scholarly communication activities (RQ1), we consider our findings overall. Based on gathered ARL data, scholarly communication information professionals with the title Scholarly Communication Librarian emerged in academic libraries in force through the 2010s. The upward trend in the growth of this position indicates that this aspect of the information professions is in demand and that the work being done is both necessary and appreciated.

Consensus about competencies suggests that the information professions agree about what ought to be done in support of researchers as they seek assistance with digital curation and research data management. This implies that the role of the scholarly communication information professional, at least in terms of his/her work in these areas, is becoming formalized. We take the formalization of digital curation work to be an indicator of the maturation of the field as it coalesces around established competencies.

Based on reviewed literature and study findings, the time between 2009 and 2015 appears to have been pivotal in the formation and coalescence of scholarly communication work by information professionals. In 2009, the ACRL Scholarly Communication Roadshow began educating librarians and other information professionals about scholarly communication. By 2012, ARL had begun to collect data on positions with the title Scholarly Communication Librarian but did not find it had enough data to warrant reporting it separately from other positions. A divergence in data collection classifications was allowed to form between Scholarly Communication and Digital Curation, despite overlap in the work carried out. In 2012, respondents to the COPPUL survey supplied data indicating scholarly communication as an area of specialization had not coalesced..$^{70}$ Yet, by 2013, ARL was collecting data about scholarly communication librarians with more than 50 positions in the 125 ARL libraries. In 2015 and 2016, two separate competencies/skills documents were published that indicated 78 percent agreement in terms of the required skills and competencies for the subarea of digital curation, identifying what is core in this area. ${ }^{71}$ By 2017, the ACRL Roadshow organizers found the knowledge of audience members had improved to the point where it was necessary to reconfigure the curriculum, implying that a level of formalization had occurred in the information professions and the information agencies sending participants. ${ }^{72}$ 
Further evidence for the emerging cohesiveness of practice in the subarea of digital curation (and research data management) comes from findings associated with the three competencies documents that we examined. These documents were published at extreme ends of what the literature points to as a formative period for the field of scholarly communication within information agencies; they were also published before and after the establishment of the area as a formal title by ARL. The Matrix of Digital Curation Knowledge (2009) is the most different of the three competencies documents studied, implying that, since its publication, the subarea of digital curation has coalesced. The competencies identified in 2015 (Preparing the Workforce for Digital Curation) and 2016 (Librarians' Competencies Profile for Research Data Management) demonstrate a mature understanding of this area of scholarly communication information work. All but one of the competencies in the 2009 document are included in later documents. Further, six of the 23 competencies shared by the 2015 and 2016 documents are unique to newer publications, having been identified and added since 2009. We interpret this as evidence of the maturation of this subarea of practice within ARL information agencies and as a de facto formalization of associated work.

\section{Scholarly Communication Work Supporting Research}

Table 2 demonstrates that scholarly communication skills and competencies, as relating to data, support the various stages of the research lifecycle. This addresses the second research question (RQ2). Not only, however, does scholarly communication work support the stages, but at least one skill/competency that is CORE to all three documents supports each stage. In fact, as work in scholarly communication has evolved, emerging skills and competencies are appearing throughout the various stages as well. The product of an organic growth process, the skills and competencies that have emerged seem to fit, by design, throughout the research lifecycle's stages. Unsurprisingly, the skills and competencies that do not map directly to support of the research cycle are generally auxiliary, only appearing in one or two of the documents examined.

Faniel and Connaway ${ }^{73}$ find that academic librarians supporting research data management interviewed in 2012 and 2013 conclude that "there are still opportunities to more efficiently and effectively support the broad range of activities throughout the data lifecycle" ${ }^{14}-\mathrm{a}$ notion that this research project explores. We find that not only was the field in the process of coalescing at the time Faniel and Connaway were carrying out their interviews, but that, shortly after the fact, the field did in fact coalesce and the opportunities to support researchers were maximized and subsequently codified.

\section{Rogers and Scholarly Communication Librarians}

As mentioned earlier, Rogers identifies four causal factors that determine whether an innovation will spread: an innovation, communication, time, and a social system. ${ }^{75}$ This work focuses on one innovation and the social system(s) in which scholarly communication positions are situated, as well as where work is carried out. For instance, in the information professions, scholarly communication positions appear to have diffused to ARL libraries through a process of disciplinary education (such as the Scholarly Communications Roadshow). Within ARL libraries, changes in scholarly communication have also required the development of additional skills and competencies for information professionals; this has resulted in increasing numbers of position titles, but also in the codification of that field. 
We cannot comment on exactly how agreed-upon skills came to coalesce in the information professions or how individual libraries created individual positions. That said, however, as per Rogers, we can assume that, at some point, individual libraries learned how to support scholars in a changing research environment and were faced with a decision of whether to restructure. Increasingly, over time, ARL libraries created these positions, which means that internal decision-makers set an agenda (they had to sign off on doing so), matched the idea of creating a specialized support position to identified needs, redefined positions to fit local needs, and restructured to create positions that showed up in ARL survey data. ${ }^{76}$ In short, available evidence suggests that ARL libraries went through an innovation-decision process, much like Rogers's model.

Equally important, however, is Rogers's concept of formalization. Within individual libraries, data suggests that library restructurings created new positions informed by, or similar to, those described in competencies documents. ${ }^{77}$ These documents mapped to the RIN/NESTA research lifecycle model. Based on these findings, then, we conclude that the work provided by these positions is valuable in the sense discussed by Ma and Wang. ${ }^{78}$ What remains less clear, however, is the best way to ensure the work these professionals do is recognized, used, and valued throughout ARL-member universities. Rogers refers to this process as clarifying and routinizing, which means ensuring that scholars use the scholarly communications services now offered and manage them effectively. Faniel and Connaway ${ }^{79}$ find that academic librarians supporting research data management interviewed in 2012 and 2013 were constrained by five factors, including technical resources (53\%) and researchers' perceptions (25\%). One "librarian noted researchers' resistance to adopting new services once they established their own practices. Considering these challenges, librarians expressed concerns about not getting involved" and another noted that the library was late to support RDM needs of researchers. ${ }^{80}$ After examining 185 library websites in 2015 for research data management services, Yoon and Schultz conclude that "libraries need to advance and engage more actively to provide services, provide information online, and develop educational services. There is also a wide variation among library data management services and programs according to their web presence." 81 Given the nature of the findings of this research, and the support that Rogers's theory provides, we return to the question of how librarians can best show their ability to integrate with researchers' processes and support their scholarly work as a topic, among others, for future study.

\section{Study Limitations and Future Work}

There are a number of limitations to the current study, which analyzes documents and models as a point of departure in lieu of interviewing scholarly communication librarians about their work, qualifications, and job descriptions. Are these positions all held by the unicorns of the profession? If not, what are the incumbents' abilities to support the stages of the research lifecycle as portrayed in the RIN/NESTA model? Because we have not ascertained specifics about how best practices are implemented in ARL libraries, we are unable to map actual practices to the needs presented in the research lifecycle, only disciplinary competencies.

Speaking about the process by which organizations "choose" to adopt or reject an innovation, Rogers notes how the process is not linear; at any point, steps in his model may be skipped, left unfinished, or started again later. ${ }^{82}$ Without data to test Rogers's model, we do not know precisely who made decisions to hire scholarly communication professionals in 
ARL information agencies, if positions explicitly matched those described in competencies documents, and if staff communicate with stakeholders to demonstrate the value that they provide. Furthermore, we cannot tell how information professionals in ARL libraries learned about scholarly communications positions or if positions ever spontaneously emerged, though it is likely that traditional professional communication networks played a key role.

With the codification of the field, is the next phase a need for consistent and strong message to be crafted and disseminated to all users, regardless of institution? What about smaller institutions that lack the infrastructure (or that have not made the hires or restructured job lines) to accommodate supporting researchers fully? Therefore, because organizational size is a factor to consider, future work should look at information agencies other than ARL libraries, because these libraries tend to be very large.

\section{Conclusion}

Our findings reveal that the work of scholarly communication information professionals has formalized since 2009. Using Rogers's Diffusion of Innovations model, we infer that there is value in the work these professionals do and conclude that the field is entering into a period of clarifying itself (using Rogers's terminology) that is indicative of its move to maturation. Given the coalescence of practice in the subarea of digital curation, scholarly communication will likely continue to remain a sustainable area of practice in the information professions. The field is positioned well to support researchers in the research process through assistance in with the seven stages of research as defined by RIN/NESTA and the related outputs. More work, however, remains to be done. The changes in position titles, with increasing numbers of scholarly communication and digital curation librarians in ARL, are indicative of the innovation that this field represents and its diffusion. The literature suggests that more needs to be done to communicate the value of the skills and competencies of these librarians to their clients moving forward.

\section{Acknowledgments}

The authors would like to thank ARL for providing access to its data.

This article is based in part on a paper presented at the Association for Information Science and Technology (ASIS\&T) Annual Meeting 2018. ${ }^{83}$ 


\section{APPENDIX A.}

Models

Research Process

Center for Open Science, “The Open Science Framework” (n.d.), available at https://cos.io/ our-products/osf/

University of Michigan, "Office of Research and Sponsored Projects" (n.d.), available at https:// orsp.umich.edu/

University of Notre Dame, "The Research Lifecycle" (n.d.), available at https://research.nd.edu/ our-services/faqs/

Monash University, “Research Lifecycle” (n.d.), available at https://www.monash.edu/library/ researchers

Graham Stone, Chris Awre, Paul Stainthorp, and Jill Emery, UK Open Access Life Cycle: For Researchers, (University of Huddersfield, 2016), available at https://doi.org/10.5920/ UKOARES.2016

Ivo Grigorov et al., Research Lifecycle Enhanced by an "Open Science by Default" Workflow (2016), available at $\mathrm{http}: / / \mathrm{dx}$.doi.org/10.5281/zenodo.49960

Research Information Network and the National Endowment for Science, Technology, and the Arts, Open to All? Case Studies of Openness in Research (September 2010), available at www. rin.ac.uk/system/files/attachments/NESTA-RIN_Open_Science_V01_0.pdf

\section{Data Models}

Sarah Higgins, "The DCC Curation Lifecycle Model." International Journal of Digital Curation 3, no. 1 (2008), available at www.ijdc.net/index.php/ijdc/article/view/69

\section{Notes}

1. Meghan Kowalski, "Breaking Down Silo Walls: Successful Collaboration across Library Departments," Library Leadership \& Management 31, no. 2 (2017): 1-15.

2. Andrea M. Ketchum, "The Research Life Cycle and the Health Sciences Librarian: Responding to Change in Scholarly Communication," Journal of the Medical Library Association 105, no. 1 (2017): 80-83, https://doi.org/10.5195/ jmla.2017.110.

3. Andrew Martin Cox and Wan Ting Tam, "A Critical Analysis of Lifecycle Models of the Research Process and Research Data Management," Aslib Journal of Information Management 70, no. 2 (2018): 142-57.

4. William Cross, Jenny K. Oleen, and Anali Perry, "Jump Start Your Scholarly Communication Initiatives: Lessons Learned From Redesigning the Scholarly Communications Roadshow for a New Generation of Librarians," in At the Helm: Leading Transformation: Proceedings of the ACRL 2017 Conference March 22-25, 2017, ed. Dawn Miller (Chicago, IL: Association of College \& Research Libraries, 2017), 365, available online at www.ala.org/acrl/ sites/ala.org.acrl/files/content/conferences/confsandpreconfs/2017/JumpStartYourScholarlyCommunicationInitiatives.pdf [accessed 1 March 2018].

5. Marinus Swanepoel et al., “Developing a Community of Practice: Report on a Survey to Determine the Scholarly Communication Landscape in Western Canada" (unpublished manuscript, 2015), available online at https://hdl.handle.net/10133/4784 [accessed 27 January 2020].

6. Cross, Oleen, and Perry, "Jump Start Your Scholarly Communication Initiatives."

7. For example, Clayton Hayes and Heidi Kelly, "Who's Talking about Scholarly Communication? An Examination of Gender and Behavior on the SCHOLCOMM Listserv," Journal of Librarianship and Scholarly Communication 5, no. 1 (2017): eP2171, https://doi.org/10.7710/2162-3309.2017; a survey of data librarians by Thomas and Urban, published in 2018, acknowledges that they received 105 usable responses but do not know the percentage of the field that represents: Camille V.L. Thomas and Richard J. Urban, "What Do Data Librarians Think of the MLIS? Professionals' Perceptions of Knowledge Transfer, Trends, and Challenges," College \& Research Libraries 79, no. 3 (2018): 401-23, https://doi.org/10.5860/crl.79.3.401. 
8. Steve Brantley, Todd A. Bruns, and Kirstin I. Duffin, "Librarians in Transition: Scholarly Communication Support as a Developing Core Competency," Journal of Electronic Resources Librarianship 29, no. 3 (2017): 137.

9. John J. Regazzi, Scholarly Communications: A History from Content as King to Content as Kingmaker (Lanham, MD: Rowman \& Littlefield, 2015).

10. Tony Hey, Stewart Tansley, and Kristin M. Tolle, The Fourth Paradigm: Data-Intensive Scientific Discovery (Redmond, WA: Microsoft Research, 2009).

11. Michael Stebbins, Expanding Public Access to the Results of Federally Funded Research (Washington, DC: U.S. Office of Science and Technology Policy, 2013), available online at https://obamawhitehouse.archives.gov/ blog/2013/02/22/expanding-public-access-results-federally-funded-research [accessed 1 March 2018].

12. Thomas and Urban, "What Do Data Librarians Think of the MLIS?"

13. Thomas and Urban, "What Do Data Librarians Think of the MLIS?" 401.

14. Thomas and Urban, "What Do Data Librarians Think of the MLIS?"

15. Thomas and Urban, "What Do Data Librarians Think of the MLIS?"

16. Jenny S. Bossaller and Heather Moulaison Sandy, "Documenting the Conversation: A Systematic Review of Library Discovery Layers," College \& Research Libraries 78, no. 5 (2017): 602-19, https://doi.org/10.5860/crl.78.5.602; Kowalski, "Breaking Down Silo Walls."

17. Christine L. Borgman, "Digital Libraries and the Continuum of Scholarly Communication," Journal of Documentation 56, no. 4 (2000): 415.

18. Therese F. Triumph and Penny M. Beile, “The Trending Academic Library Job Market: An Analysis of Library Position Announcements from 2011 with Comparisons to 1996 and 1988," College E Research Libraries 76, no. 6 (2015): 716-39, https://doi.org/10.5860/crl.76.6.716.

19. John Novak and Annette Day, "The Libraries They Are A-Changin': How Libraries Reorganize," College $\mathcal{E}$ Undergraduate Libraries 22, no. 3/4 (2015): 358-73, https://doi.org/10.1080/10691316.2015.1067663.

20. Triumph and Beile, "The Trending Academic Library Job Market."

21. Ayoung Yoon and Teresa Schultz, "Research Data Management Services in Academic Libraries in the US: A Content Analysis of Libraries' Websites," College \& Research Libraries 78, no. 7 (Nov. 2017): 920-33, https:// doi.org/10.5860/crl.78.7.920.

22. Liat Klain-Gabbay and Snunith Shoham, "Scholarly Communication and Academic Librarians," Library E Information Science Research 38, no. 2 (2016): 170-79.

23. Sarah Potvin, "The Principle and the Pragmatist: On Conflict and Coalescence for Librarian Engagement with Open Access Initiatives," Journal of Academic Librarianship 39, no. 1 (2013): 67-75; Julia E. Rodriguez, "Scholarly Communications Competencies: Open Access Training for Librarians," New Library World 116, no. 7/8 (2015): 397-405, https://doi.org/10.1108/NLW-12-2014-0140.

24. David Fearon et al., ARL SPEC Kit 334: Research Data Management Services (Washington, DC: Association of Research Libraries, 2013), https://doi.org/10.29242/spec.334.

25. Fearon et al., ARL SPEC Kit 334: Research Data Management Services, 56.

26. Nancy L. Maron and K. Kirby Smith, Current Models of Digital Scholarly Communication: Results of An Investigation Conducted by Ithaka for the Association of Research Libraries (Washington, DC: Association of Research Libraries, 2008), available online at https://www.arl.org/wp-content/uploads/2008/11/digital-sc-models-report-2008. pdf.pdf [accessed 27 January 2020]; Nancy L. Maron and K. Kirby Smith, "Current Models of Digital Scholarly Communication: Results of an Investigation Conducted by Ithaka for the Association of Research Libraries," Journal of Electronic Publishing 12, no. 1 (2009), https://doi.org/10.3998/3336451.0012.105.

27. Ruth Lewis, Sarli Cathy, and Amy Suiter, ARL SPEC Kit 346: Scholarly Output Assessment Activities (Washington, DC: Association of Research Libraries, 2015), https://doi.org/10.29242/spec.346.

28. Cox and Tam, "A Critical Analysis of Lifecycle Models of the Research Process and Research Data Management."

29. Cox and Tam, "A Critical Analysis of Lifecycle Models of the Research Process and Research Data Management."

30. Cox and Tam, "A Critical Analysis of Lifecycle Models of the Research Process and Research Data Management."

31. Cox and Tam, "A Critical Analysis of Lifecycle Models of the Research Process and Research Data Management," 143.

32. Cox and Tam, "A Critical Analysis of Lifecycle Models of the Research Process and Research Data Management."

33. University of Michigan, "Office of Research and Sponsored Projects" (n.d.), available online at https:// orsp.umich.edu/ [accessed 15 January 2019].

34. Carol Tenopir et al., "Data Sharing by Scientists: Practices and Perceptions," PloS One 6, no. 6 (2011): e21101, 
https://doi.org/10.1371/journal.pone.0021101.

35. Feicheng Ma and Wang Juncheng, "A Literature Review of Studies on Information Lifecycle I: The Perspective of Value," Journal of the China Society for Scientific and Technical Information 29, no. 5 (2010a): 939-47; Feicheng Ma and Wang Juncheng, "The Review of Studies on Information Lifecycle II: the Perspective of Management," Journal of the China Society for Scientific and Technical Information 29, no. 6 (2010b): 1080-86.

36. Jake Carlson, "The Use of Life Cycle Models in Developing and Supporting Data Services," in Research Data Management: Practical Strategies for Information Professionals, ed. J.M. Ray (West Lafayette, IN: Purdue University Press, 2014), 63-86.

37. Knud Möller, "Lifecycle Models of Data-Centric Systems and Domains," Semantic Web 4, no. 1 (2013): 67-88.

38. Cox and Tam, "A Critical Analysis of Lifecycle Models of the Research Process and Research Data Management."

39. Elliott D. Green, "What Are the Most-Cited Publications in the Social Sciences (according to Google Scholar)?" Impact of Social Sciences Blog (May 2016), available online at http://eprints.lse.ac.uk/66752/ [accessed 1 March 2018].

40. Everett M. Rogers, Diffusion of Innovations (New York, NY: Free Press, 2003), 11-12.

41. Thomas W. Valente and Everett M. Rogers, "The Origins and Development of the Diffusion of Innovations Paradigm as an Example of Scientific Growth," Science Communication 16, no. 3 (1995): 242-73.

42. Rogers, Diffusion of Innovations, 11.

43. "Organization," in English Oxford Living Dictionaries (n.d.), available online at https://en.oxforddictionaries. com/definition/organization [accessed 1 March 2018].

44. Rogers, Diffusion of Innovations.

45. We assume this idea spread through the information professions as opposed to spontaneously emerging in libraries.

46. Peter Jordan and Caroline Lloyd, Staff Management in Library and Information Work, 4th ed. (New York, NY: Routledge, 2017).

47. Rogers, Diffusion of Innovations, 421.

48. Rogers, Diffusion of Innovations, 427.

49. Rogers, Diffusion of Innovations, 429.

50. Derek S. Pugh, Organization Theory: Selected Readings (Harmondsworth, UK: Penguin, 1990), 1.

51. Rogers, Diffusion of Innovations.

52. Rogers, Diffusion of Innovations, 411.

53. Jerald Hage and Michael Aiken, "Program Change and Organizational Properties: A Comparative Analysis," American Journal of Sociology 72, no. 5 (1967): 503-19.

54. Helen A. Howard, "Organizational Structure and Innovation in Academic libraries," College \& Research Libraries 42, no. 5 (1981): 425-34.

55. Shin T. Chen and Bao G. Chang, "The Effects of Absorptive Capacity and Decision Speed on Organizational Innovation: A Study of Organizational Structure as an Antecedent Variable," Contemporary Management Research 8, no. 1 (2012): 27-50, https://doi.org/10.7903/cmr.7996.

56. Rogers, Diffusion of Innovations.

57. See: Thomas and Urban, "What Do Data Librarians Think of the MLIS?"

58. Christopher Lee, Matrix of Digital Curation Knowledge and Competencies (2009), available online at https://ils. unc.edu/digccurr/digccurr-matrix.html [accessed 1 March 2018 ]; National Research Council, Preparing the Workforce for Digital Curation (Washington, DC: The National Academies Press, 2015), https://doi.org/10.17226/18590; Pascal Calarco et al., Librarians' Competencies for Scholarly Communication and Open Access (Confederation of Open Access Repositories, June 2016), available online at https:/www.coar-repositories.org/files/Competencies-forScholComm-and-OA_June-2016.pdf [accessed 1 March 2018].

59. Johnny Saldaña, The Coding Manual for Qualitative Researchers, 2nd ed. (Thousand Oaks, CA: Sage, 2013).

60. Cynthia Hudson-Vitale, Heather Moulaison Sandy, A.J. Million, Data set (2018), https://doi.org/10.26207/ c0v9-qn33.

61. Research Information Network and the National Endowment for Science, Technology, and the Arts (RIN/ NESTA), Open to All? Case Studies of Openness in Research (Sept. 2010), available online at www.rin.ac.uk/system/ files/attachments/NESTA-RIN_Open_Science_V01_0.pdf [accessed 15 January 2019].

62. Cox and Tam, "A Critical Analysis of Lifecycle Models of the Research Process and Research Data Management,"146.

63. Cox and Tam, "A Critical Analysis of Lifecycle Models of the Research Process and Research Data Management." 
64. Cox and Tam, "A Critical Analysis of Lifecycle Models of the Research Process and Research Data Management," 152.

65. RIN/NESTA, Open to All? 14.

66. Ma and Wang, "A Literature Review of Studies on Information Lifecycle I"; Ma and Wang, "The Review of Studies on Information Lifecycle II."

67. Carlson, "The Use of Life Cycle Models in Developing and Supporting Data Services."

68. Ivo Grigorov et al., Research Lifecycle Enhanced by an "Open Science by Default" Workflow (2016), http://dx.doi. org/10.5281/zenodo.49960; Tenopir et al., "Data Sharing by Scientists."

69. RIN/NESTA, Open to All? key stages, 13-14, outputs, 15.

70. Swanepoel et al., "Developing a Community of Practice."

71. National Research Council, Preparing the Workforce or Digital Curation; Calarco et al., Librarians' Competencies for Scholarly Communication and Open Access.

72. Cross, Oleen, and Perry, "Jump Start Your Scholarly Communication Initiatives."

73. Ixchel M. Faniel and Lynn Silipigni Connaway, "Librarians' Perspectives on the Factors Influencing Research Data Management Programs," College E Research Libraries 79, no. 1 (2018): 100-19, https://doi.org/10.5860/ crl.79.1.100.

74. Faniel and Silipigni Connaway, "Librarians' Perspectives on the Factors Influencing Research Data Management Programs," 115.

75. Rogers, Diffusion of Innovations, 11.

76. Rogers, Diffusion of Innovations, 421.

77. Rogers, Diffusion of Innovations, 411.

78. Ma and Wang, "A Literature Review of Studies on Information Lifecycle I."

79. Faniel and Silipigni Connaway, "Librarians' Perspectives on the Factors Influencing Research Data Management Programs."

80. Faniel and Silipigni Connaway, "Librarians' Perspectives on the Factors Influencing Research Data Management Programs."

81. Yoon and Schultz, "Research Data Management Services in Academic Libraries in the US," 930.

82. Rogers, Diffusion of Innovations, 421.

83. A. J. Million, Heather Moulaison Sandy, and Cynthia Hudson-Vitale, "Restructuring and Formalizing: Scholarly Communication as a Sustainable Growth Opportunity in Information Agencies?" Proceedings of the Association for Information Science and Technology 55, no. 1 (2018):377-86, https://doi.org/10.1002/pra2.2018.14505501041. 